\title{
The Reform(s) of Universal Jurisdiction in Spain: For Whom the Bells Tolls?
}

\author{
Javier ChINCHÓN Álvarez*
}

The issues I was suggested to address in this Agora have led me to opt against providing a detailed analysis of the Act I/2014, of I3 March on the Modification of the Judiciary Act of 6/1985, of I July Regarding Universal Justice (LO I/20I4). ${ }^{\mathrm{L}}$ Likewise I have chosen not to use this limited space to present again my personal opinion of that Act in form and substance. ${ }^{2}$ In order to offer some ideas for reflection and debate, I believe it is important to examine this recent reform from a broader perspective: that is (to use the oft-heard formula) we should take the occasion to focus not on the specific item but on the trend of which it forms part. This forces us, in my opinion, to bear witness to a scenario that may form part of a pattern - alas, not an extraordinary one- which extends beyond this specific issue, and which appears especially intense and palpable in recent years.

To briefly make note of my evaluation of the LO I/20I4 from an international legal perspective, I would say I coincide generally with the opinion summarized in a document signed by over a hundred

Lecturer in International Law and International Relations, Universidad Complutense de Madrid, and Research Director of Rights International Spain. E-mail: jachal@der.ucm.es. This article forms part of the Research Project DER 2012-36I42 (Carlos III University of Madrid), funded by the Spanish Ministry of Economy and Competitiveness.

Ley Orgánica I/20I4, de I3 de marzo, de modificación de la Ley Orgánica 6/1985, de I de julio, del Poder Judicial, relativa a la justicia universal (LO I/2014), in B.O.E. $\mathrm{n}^{\circ}$. 63, $\mathrm{I} 4$ March 2014, 23026-23031, text available at <http://www.boe.es/boe/dias/2014/03/14/pdfs/BOE-A-2014-2709.pdf>, accessed 20 September 2014. For a detailed analysis: R. A. Alija Fernández, 'Crónica de una muerte anunciada: análisis de la Proposición de Ley Orgánica para la reforma de la justicia universal en España', Revista catalana de dret públic, (20I4), available at <http://blocs.gencat.cat/blocs/AppPHP/eapc-rcdp/2014/o2/o5/cronica-de-una-muerte-anunciada-analisis-de-la-proposicionde-ley-organica-para-la-reforma-de-la-justicia-universal-en-espana-rosa-ana-alija/>, accessed 23 September 2014; F. J. Álvarez García, A. M. Garrocho Salcedo and A. Martínez Guerra, Informe sobre la Proposición de Ley Orgánica de modificación de la Ley Orgánica 6/85, de I de julio, del Poder Judicial, relativa a la Justicia Universal (Human Rights Section of the Ilustre Colegio de Abogados de Madrid, 2014), text available at <http://web.icam.es/bucket/INFORME\%20SECCION\%20DDHH\%20ICAM_PROYECTO\%20REFORMA\%20LOPJ.p df>, accessed 20 September 2014 ; A. Martínez Guerra, 'La reforma de la "molesta" jurisdicción universal y sus primeras consecuencias', 7 Eunomía-Revista en Cultura de la Legalidad (2014) II7-I42, available at <http://hostingor.uc3m.es/Erevistas/index.php/EUNOM/article/view/2236/II72>, accessed 29 September 20I4; A. Sánchez Legido, 'El fin del modelo español de jurisdicción universal', 27 Revista Electrónica de Estudios Internacionales (2014) I-40, text available at <http://www.reei.org/index.php/revista/num27/articulos/fin-modelo-espanol-jurisdiccion-universal>, accessed 25 September 2014; A. Segura Serrano, 'Hacia una nueva reforma restrictiva del principio de jurisdicción universal en España', 66-I Revista Española de Derecho Internacional (2014) 32I-324.

2 For the reader interested in my point of view, J. Chinchón Álvarez, 'Del intento de acabar con la jurisdicción universal para el bien de las víctimas y del Derecho internacional: Examen crítico de la Ley Orgánica I/20I4, de I3 de marzo, de modificación de la Ley Orgánica 6/1985, de I de julio, del Poder Judicial, relativa a la justicia universal', 5 Revista de Derecho Penal y Criminología, (2014) I6I-173, text available at <https://www.academia.edu/7298874/Chinchon_Alvarez_Javier_20I4_Del_intento_de_acabar_con_la_jurisdiccion_universal_ para_el_bien_de_las_victimas_y_del_Derecho_internacional_Examen_critico_de_la_Ley_Organica_I_20I4_de_I3_de_marzo_d e_modificacion_de_la_Ley_Organica_del_Poder_Judicial_relativa_a_la_justicia_universal>, accessed 20 September 2014. 
organizations in early February of this year, ${ }^{3}$ which was later upheld by the Judge Pedraz (among others) in the March $17^{\text {th }}$ decision regarding what is known as the "Couso Case", ${ }^{4}$ as well as by the judges Sáez Valcárcel, de Prada Solaesa, Murillo Bordallo and Bayarri García - with the support of the Judge Díaz Delgado- in their dissenting vote on July $10^{\text {th }}$ with regard to what is referred to as the "Tibet case." We should recall that in this case the majority in the Plenary of the Criminal Chamber of the Audiencia Nacional ${ }^{6}$ tried to disregard the question through what I consider a most questionable abstraction of the true object of the trial, accompanied by an incomprehensible choice of which regulations and penal categories to apply. But, in any case, none of this stopped them from upholding that there is no international law that obliges States to transpose the principle of universal jurisdiction into their internal legal code. ${ }^{7}$ As I have already said, I will not detail my opinion on this here, but I will cite one of the statements made in that vote, with which I fully concur:

When we speak of universal jurisdiction in war crimes [...] we must take note that that principle implies the extension of a State's jurisdiction solely on the basis of the of the nature of the crime. Therefore, when a connection is required-be it through the nationality of the perpetrator, the nationality of the victim, or the interests of the State- other mechanisms of attributing jurisdiction are applied (active or passive personality principle, principle of protection or defense) [...]

By establishing requirements regarding the nationality of the perpetrator, his/her habitual residence or presence in Spain, and the refusal of extradition requests in the persecution of genocides and war criminals, the legislators have intentionally invalidated the universal jurisdiction associated with these crimes. ${ }^{8}$

In these accurate observations we can hear the echo of the famous ruling of the Constitutional Court regarding what is known as the "Guatemala Case", 9 but I think it best to turn to another important document from this very year, 20I4, focusing on what doctrine has come to call international crimes in the first degree'10, that is, those crimes in which "mankind is also the victim" (according to the

3 'Los legisladores españoles deben rechazar la reforma propuesta que pretende cerrar la puerta a la justicia para los crímenes más graves. La proposición de ley supone una grave limitación de la jurisdicción universal sobre crímenes de derecho internacional y violaría tratados internacionales fundamentales', io Febraury 20I4, text available at <http://www.rightsinternationalspain.org/uploads/publicacion/071425856d4c50c5Ic435fd69ad8fb2beazacd2e.pdf>, accessed 20 September 20I4.

4 Decision on 17 March 2014, Investigative Chamber no. I of the Audiencia Nacional, text available at <http://www.rightsinternationalspain.org/uploads/noticia/e448326a2550d9rir6e8d58Ic346c27e57758a86.pdf>, accessed 20 September 20I4.

5 Text

available

<http://www.rightsinternationalspain.org/uploads/noticia/2e51acd815a796e46986ce63693448627f37e217.pdf>, accessed 20 September 20I4.

6 National Court of Spain.

7 Supra n. 5, at 6.

8 "Cuando se babla de jurisdicción universal de los crímenes de guerra, [...], bay que reparar en que dicho principio implica la extensión de la jurisdicción del Estado en atención al único criterio de la naturaleza del delito. Por ello, cuando se exigen vínculos de conexión relacionados con la nacionalidad del perpetrador, la nacionalidad de la víctima o los intereses del Estado, se aplican otros mecanismos de atribución de la jurisdicción (principio de personalidad activa o pasiva y principio de protección o de defensa). [...] Al establecer para la persecución de los de los genocidas y de los criminales de guerra y de lesa bumanidad exigencias en relación a la nacionalidad del perpetrador, su residencia habitual o estancia en España más denegación de solicitud de extradición, el legislador ba querido dejar sin vigencia la jurisdicción universal asociada a los mismos”. Supra n. 5, at 7 and 9.

9 Constitutional Court, judgment 237/2005, 26 September 2005.

ro M. Ollé Sesé, Justicia universal para crímenes internacionales (La Ley, Madrid, 2008). 
classic formulation by the International Law Commission). ${ }^{\text {II }}$ These are crimes which, in the words of Professor Abellán Honrubia, affect interests which international practice, jurisprudence and specialized doctrine consider not specific to any given State but rather fundamental interests of the whole international community, and are therefore to be protected by international law. ${ }^{\mathrm{I} 2}$ That said, last February $19^{\text {th }}$, nineteen of the Prosecutors of the Audiencia Nacional determined that the application of $\mathrm{LO} \mathrm{I} / 2014$ represented an attempt:

... to shelve indiscriminately nearly all the proceedings which have arisen through the exercise of universal jurisdiction and which are being processed by the judicial bodies of the Spanish National High Court, thus leaving empty of content such basic constitutional rights as access to jurisdiction and effective judicial protection in the face of such grave crimes, as well as the protection of the rights of the victim. ${ }^{\mathrm{I}}$

This same document complains that applying the criteria called for by the LO I/20I4 will help to create spaces of impunity by neutralizing judicial capacity to respond and to investigate, and by making it more difficult to fulfill international obligations and commitments which have been assumed for the purpose of combating the most serious forms of crime and guaranteeing the rights of citizens. ${ }^{14}$ As we will see shortly, the opinion presented by the legislative majority tried to convince us that the objective was in fact just the opposite, but before addressing that -as I said in the beginning- let us look back for a moment. Of the many references we might cite, let us turn to another recent text: the evaluation by our Supreme Court of the "transformation" we have witnessed in recent years, leading up to the $\mathrm{LO}$ I/20I4. Its ruling from July $23^{\text {rd }} 2014$ states:

The regulation of international justice in our legal framework has experienced a transformation, starting with the promulgation of the Law of Judicial Power (Ley Orgánica del Poder Judicial) which might be defined as pure universal justice, in as much as it lacks any legal conditions; a second change with the modification which became effective in 2009 ( $\mathrm{LO}_{\mathrm{I}} / 2009$, November $3^{\text {rd }}$ ), which we might describe as universal justice with the requirement of some national connection or a relevant bond placing us in direct relation to the event being prosecuted; and the present legislation, instated with the LO I/20I4 of March $\mathrm{I}^{\text {th }}$, in which weight is principally given to the configuration of international treaties and the degree to which these attribute jurisdiction to signatory States. ${ }^{15}$

II Yearbook of the International Law Commission 1950, vol. II, at 9.

I2 V. Abellán Honrubia, 'La responsabilité internationale de l'individu', 280 Recueil des Cours de l'Académie de Droit International de La Haye, (1999) 135 , at 295.

13 “... de forma indiscriminada el archivo de la práctica totalidad de los procedimientos relacionados con el ejercicio de la jurisdicción universal que se tramitan ante los órganos judiciales de la Audiencia Nacional, vaciando de contenido derechos constitucionales básicos como el acceso a la jurisdicción y la tutela judicial efectiva frente a la ejecución de tan graves delitos, y la protección de los derechos de las víctimas." State Public Prosecutor, 'Memoria elevada al Gobierno de S.M. Presentada al inicio del año judicial por el Fiscal General del Estado Excmo. Sr. D. Eduardo Torres-Dulce Lifante' (20I4) at 235, text available at <https://www.fiscal.es/fiscal/PA_WebApp_SGNTJ_NFIS/descarga/MEMFISI4.pdf?idFile=dd 3 ff 8 fc-doc5-472e-84d223 Ibe24bc4b2 $>$, accessed 24 September 2014.

14 Ibid., at 236.

is "La regulación de la justicia internacional en nuestro ordenamiento jurídico ba sufrido una evolución que, sintéticamente, podemos señalar que, tras la promulgación de la Ley Orgánica del Poder Judicial, ba de definirse como de pura justicia universal, en tanto que carecía de cualquier condicionante jurídico; una segunda, inaugurada mediante la modificación operada en 2009 (LO I/2009, de 3 de noviembre), que podremos adjetivar de justicia universal con exigencia de una conexión nacional, o vínculo relevante que nos relacione con el becho perseguido; y la vigente, que nace con la Ley Orgánica I/20I4, de I3 de marzo, en donde preponderantemente se atiende a la configuración de los tratados internacionales y el grado de atribución de jurisdicción que otorgan a los Estados firmantes." Supreme Court, judgment 592/2014, 23 July 2014, at 17. 
The widespread and incorrect impression that International Law resides solely in international treaties' aside, I can not take the time here to comment upon the peculiar description that the Supreme Court makes of the content of the LO I/20I4; nor upon what it mentions regarding the LO $\mathrm{I} / 2009{ }^{16}$ that is, the intended end to the "principle of absolute universal jurisdiction" to cite the Spanish authorities before the General Secretary of the United Nations. ${ }^{17}$ But I will indicate that to better situate this in its context, we should note that the summary presented by the Supreme Court lacks any mention of laws such as the $\mathrm{LO}$ I8/2003 on Cooperation with the International Criminal Court, ${ }^{18}$ that is, what the Public Prosecutor has described as the first time the legislature "nuanced" the reach of the principle of universal jurisdiction. ${ }^{19}$ Setting aside my own analysis how this law was intended to reverse the Principle of Complementarity that governs the relationship between the International Criminal Court and internal jurisdictions, what I wish to highlight here is that we might summarize the shifts seen in the last decade as follows: as soon as the principle of universal jurisdiction (as enshrined in our article 23.4 LOPJ) began to be applied and become a reality in the late 1990 s and the beginning of this century, it was "nuanced" in 2003. Then in 2009 its content was substantially modified in order to incorporate, by virtue of the LO I/2009, what the Constitutional Court rightly indicated would serve at the very least as "restrictive criteria". ${ }^{20}$ Now in 2014 , through the $\mathrm{LO}_{\mathrm{I}} / 2 \mathrm{OI}$, the process of demolition is complete: our courts can only continue investigating ${ }^{2 \mathrm{I}}$ and in the future can only investigate those crimes such as genocide, crimes against humanity, or the crimes generally denominated 'war crimes' when their presumed perpetrator is a Spanish citizen or a foreign citizen residing in Spain, or else a foreigner presently in Spain in the case of denied

I6 For readers interested in my analysis of the 2009 reform, see (from when the reform was still valid): J. Chinchón Álvarez, "Análisis formal y material de la reforma del principio de jurisdicción universal en la legislación española: De la 'abrogación de facto' a la 'derogación de iure’”, 4 La Ley: Revista Jurídica Española de Doctrina, Jurisprudencia y Bibliografía, (2009) I440-I450, text available at <https://www.academia.edu/5666083/Chinchon_Alvarez_Javier_2009_Analisis_formal_y_material_de_la_reforma_del_princi pio_de_jurisdiccion_universal_en_la_legislacion_espanola_De_la_abrogacion_de_facto_a_la_derogacion_de_iure_.La_Ley_72 II_-_Pp._I-8>, accessed 2I September 20I4. After the reform, "A propósito del proceso de reforma del artículo 23.4 de la Ley Orgánica del Poder Judicial (mayo-noviembre de 2009): De los motivos a las consecuencias para el principio de jurisdicción universal", 6 Revista de Derecho de Extremadura (2009), I3-3I, text available at <https://www.academia.edu/5646517/Chinchon_Alvarez_Javier_2009_A_proposito_del_proceso_de_reforma_del_articulo_23. 4_de_la_Ley_Organica_del_Poder_Judicial_mayo-

noviembre_de_2009_De_los_motivos_a_las_consecuencias_para_el_principio_de_jurisdiccion_universal._Revista_de_Derecho _de_Extremadura_6_._pp._I3-3I>, accessed 2I September 2014.

${ }^{17} \mathrm{~A} / 68 / \mathrm{II}_{3}, \quad 26 \quad$ June $2013, \quad$ at $6, \quad$ text $<$ http://www.un.org/es/comun/docs/index.asp?symbol=A\% 2 F68\% ${ }_{2} F_{11} 2 \&$ Submit=Buscar\&Lang=S $>$, accessed 20 September $2014>$.

I8 B.O.E $\mathrm{n}^{\mathrm{o}}$ 296, in December 2003, text available at <http://www.boe.es/buscar/pdf/2003/BOE-A-2003-22715consolidado.pdf $>$, accessed 2I September 2014.

19 Audiencia Nacional, report of Office of the Prosecutor, 16 November 2012, Diligencias Previas $n^{\circ}$. 197/2010, Investigative Chamber no. 5, at 16-17, text available <http://www.rightsinternationalspain.org/uploads/noticia/9re860271ee2I2bfo37a23b5ddri8rigdbe4eb6oc.pdf>, accessed 2I September 2014 .

20 Supra n. 9, at Legal Reasoning $4^{\circ}, 5^{\circ}$ and $9^{\circ}$.

${ }_{21} \quad$ As is well-known in light of the extraordinary Diposición Transitoria of the LO I/2014: "Las causas que en el momento de entrada en vigor de esta Ley se encuentren en tramitación por los delitos a los que se bace referencia en la misma quedarán sobreseídas basta que no se acredite el cumplimiento de los requisitos establecidos en ella". 
extradition. At the same time, should any doubts remain, the text adds (in article 23.6) that public action may not be what initiates these proceedings, expelling from the equation an element which has been key in so many of the trials brought forward under the principle of universal jurisdiction.

In my opinion both the most striking thing about this 'transformation' and the element which should impel us to a deeper reflection is that - centering our attention upon the principle reforms the underlying motivations in both cases seem to coincide completely, and the reasons brandished in order to justify them appear nearly identical. The most apparent formal difference, in fact, is a matter of timing, even efficiency: in the case of the 2009 reform, the process was resolved in just five months; in the 2014 reform it took less than two.

As some will remember, in the process of the modification in 2009 it was common to hear both in the Congress and the Senate that the reform was justified by the need to improve the prosecution of international crimes by our courts and to make the courts more efficient; ${ }^{22}$ and to attend to victims of these crimes better and not to disappoint them. ${ }^{23}$ According to the public declaration of the then Deputy Prime Minister of the Government, the idea was that the reform did not represent a retreat from the principle of universal jurisdiction but was rather an improvement which reaffirmed our commitment to that principle. ${ }^{24}$ All the same, even among those who defended the reform one occasionally heard little comments which alluded to the real reasons behind it, ${ }^{25}$ that is -as is well known - the pressure exerted by countries such as China, the United States or Israel, among others, when faced with developments in the judicial proceedings investigating crimes presumably committed by citizens of those countries. Due to limited space, a paradigmatic example will have to suffice: the then-Minister of Foreign Affairs of Israel, Tzipi Livni, in January of 2009 publically announced that our Ministry of Foreign Affairs had just assured her that Spain would change its legislation regarding universal jurisdiction in order to avoid "abuses of the Spanish legal system." ${ }^{26}$ Much as it was denied at the time, the fact is that by late May of that same year the text of the reform had been presented, and by October it was approved and promulgated.

In the 2014 reform, the very Preamble of the law states that since the previous reform 'reality has demonstrated' the need for a new modification. The question is clearly why. The answer offered in Parliament, in addition to incorrect appeals to a supposed international law the limits and requirements' of which seemed to compel such a change, was that the reform was to turn universal jurisdiction into something effective and useful, which would provide real results. ${ }^{27}$ Specifically, it was

\footnotetext{
${ }_{22}$ See e.g., Diario de Sesiones del Congreso de los Diputados, 25 June 2009, at 46; Diario de Sesiones del Congreso de los Diputados, 2009, 15 October 2009, at 2I.

23 Diario de Sesiones del Congreso de los Diputados, 2009, I5 October 2009, at 21.

24 “De la Vega afirma que la limitación de la justicia internacional no será un retroceso", in El País, 23 May 2009, text available at <http://elpais.com/diario/2009/05/23/espana/r243029618_850215.html>, accessed 21 September 2014.

${ }_{25}$ See e.g., Diario de Sesiones del Congreso de los Diputados, 25 June 2009, at 45; Diario de Sesiones del Senado, 7 October 2009, at 2574.

26 J. M. Muñoz and M. González, "Moratinos promete cambiar la ley para frenar al juez, según la ministra israelí", in El País, 3I January 2009, text available at <http://elpais.com/diario/2009/oI/3I/espana/I2333564I3_850215.html>, accessed 2I September 20I4.

27 See e.g., Diario de Sesiones del Congreso de los Diputados, Pleno y Diputación Permanente, II Febraury 2014, at 20; Diario de Sesiones del Senado, Io March 2014, at 17.
} 
said that article 23.4 LOPJ had to be reformed in order not to disappoint the legitimate expectations of those who recur to our courts. ${ }^{28}$ It therefore would seem that the 2009 modification fell short of these noble goals, though in this case it is even more evident that the key element was the pressure exerted by various States, especially by Chinese authorities after the extension of the lawsuit for presumed genocide against $\mathrm{Hu}$ Jintao, ex-president of the People's Republic of China was approved ${ }^{29}$ and international orders for arrest warrants against, among others, Jiang Zemin, the ex-president of China and secretary of the Chinese Communist Party, were issued..$^{30} \mathrm{I}$ cannot go into the abundance of evidence that exists here, so I will simply mention that from the very beginning of the process of modification it was stated that this reform was dear to the heart of the Ministry of Foreign Affairs. ${ }^{3 \mathrm{I}}$ It is a fact that none other than the head of this Ministry, when asked about this, declared on Spanish National Television on April $\mathrm{I}^{\text {th }}$ that there were "a series of cases which are truly dangerous from the perspective of international relations", specifically (with reference to the presumed genocide committed in Tibet) he stated literally that China owns twenty percent of Spanish public debt and just a click of the mouse in China would be enough for us to find ourselves with a market risk premium like we had some years ago, with unemployment lines to match. ${ }^{22}$ Some days later, this time on the television channel Antena 3, when asked whether China had demanded the already-approved reform, the Minister responded with laughter that "that was information that could not be disclosed. ${ }^{33}$

Many things might be said about this, but I will limit myself to what follows: the sovereignty of each and every one of us ostensibly resides in Parliament, where legislative proposals are supposedly presented and discussed with due seriousness and transparency. The representative of the Popular Party, who defended the modification of the LOPJ, stated in Parliament that this modification would serve to establish mechanisms to objectively guarantee that criminal law be able to respond effectively so as not to continue dashing the expectations of victims who recurred to the Spanish courts, thus undermining universal justice. He added, lest there be any doubt, that: This, and not the diplomatic conflicts, is what really concerns us. ${ }^{34}$

Going back to the laughter I mentioned a moment ago, the truth is that I don't find any of this at all amusing. Nor do I find admissible what was stated again and again both in 2009 and in this most recent 2014 reform: that for prosecuting international crimes we now have the International Criminal

28 Diario de Sesiones del Congreso de los Diputados, Pleno y Diputación Permanente, II February 20I4, at 25.

29 Decision on 9 October 2013, Investigative Chamber no. 2 of the Audiencia Nacional, text available at<http://www.rightsinternationalspain.org/uploads/noticia/cod25294078c8a6c8roesf2d4bb4106bc384b7ee.pdf>, accessed 2I September 2014 .

30 Decision on 18 November 2013, Investigative Chamber no. 2 of the Audiencia Nacional, text available at <http://www.rightsinternationalspain.org/uploads/noticia/7of705ddo9aacb8aba57e7dd97d8dac2e37ef5a2.pdf>, accessed 22 September 20I4.

${ }^{31} \quad$ Europa Press, 'El Gobierno acelera en el Congreso la reforma de la justicia universal que busca evitar conflictos diplomáticos', 4 Febraury 20I4, text available at<http://www.europapress.es/nacional/noticia-gobierno-acelera-congresoreforma-justicia-universal-busca-evitar-conflictos-diplomaticos-20140204I43759.html $>$, accessed 22 September 2014.

32 Available at <http://www.rtve.es/alacarta/videos/el-debate-de-la-I/debate-I-IO-04-I4/2501527/>, accessed 2I September 20I4. The cited declarations begin after minute 32 of this interview.

33 The interview itself is no longer available online, but a reference to it may be found here: <http://www.diarioprogresista.es/justicia-universal-made-in-china-51337.htm>, accessed 22 September 2014.

34 Diario de Sesiones del Congreso de los Diputados, Pleno y Diputación Permanente, in February 20I4, at 25. 
Court. Anyone even minimally familiar with this institution, its legal basis or its practical realities, can only take this as a bad joke.

It is evident that none of the reforms we've suffered in recent years has had anything to do with the better fulfillment of Spain's international obligations, much less with a concern for improving the efficiency with which our courts attend to victims of the most terrible international crimes who recur to them. What is clear is that the gradual and (with this most recent reform) nearly complete dismantling of the principle of universal jurisdiction in our LOPJ is best explained not by the pressure exerted by the authorities of other States (probably inevitable) but by the total failure of our authorities to stand up against these pressures.

In his analysis of the 2009 reform, Professor Remiro Brotóns wrote that the first impression made by the then-proposed amendment to article 23.4 of the LOPJ was pathetic, inasmuch as - among other observations which I also share- one could say that the amendment was a timely response in a moment in which the threat of criminal proceedings against leaders and former leaders of the great powers or "friendly nations" was becoming politically, diplomatically and commercially inconvenient. ${ }^{35}$ Now, in 20I4, we find that these same powers and/or these (and other) "friends" weren't satisfied with the 2009 reform, and that their new demands encounter once again a legislature which is all too happy to change our legislation to please them. This is disheartening to say the least. But to see that this can be done while avoiding any kind of serious debate worthy of the name, while claiming explicitly and formally to the citizenry (in the Congress and the Senate) that this is being done in order to reinforce our commitment to the struggle against impunity and in order not to fail the victims of the most ghastly international crimes: this, in my mind, is (yet another) disgrace.

Everyone may have their own opinions about the virtues or the disadvantages of universal jurisdiction, but I don't think anyone can feel satisfied when they see, once again, the extent to which everything enshrined in articles I.2 or 66.I of our Constitution can be blatantly turned to dust before our eyes. If many of our lawmakers feel ashamed to recognize openly, officially and publically for whom they are legislating, why, and under what demands, then it is with sadness that I can say nothing except that yes, they should be ashamed.

The last question, and the only real one, is then: in what would they not have ceded? And, above all, what will they not cede under pressure from the great powers, the more or less "friendly" states, or whoever else comes along?

\footnotetext{
35 A. Remiro Brotóns, 'Derecho y política en la persecución de los crímenes internacionales en España', in J. Tamarit Sumalla (coord.), Justicia de transición, justicia penal internacional y justicia universal (Atelier, Barcelona, 2010) 207, at 213.
} 